This item was submitted to Loughborough's Research Repository by the author.

Items in Figshare are protected by copyright, with all rights reserved, unless otherwise indicated.

\title{
Building institutional capacity for sanitation
}

PLEASE CITE THE PUBLISHED VERSION

PUBLISHER

(c) WEDC, Loughborough University

VERSION

VoR (Version of Record)

PUBLISHER STATEMENT

This work is made available according to the conditions of the Creative Commons Attribution-NonCommercialNoDerivatives 4.0 International (CC BY-NC-ND 4.0) licence. Full details of this licence are available at: https://creativecommons.org/licenses/by-nc-nd/4.0/

\section{LICENCE}

CC BY-NC-ND 4.0

\section{REPOSITORY RECORD}

Bolt, Eveline, and Kathleen Shordt. 2019. "Building Institutional Capacity for Sanitation". figshare. https://hdl.handle.net/2134/30593. 


\title{
Building institutional capacity for sanitation
}

\author{
Eveline Bolt and Kathleen Shordt, The Netherlands
}

This paper examines some challenges that continue to marginalize the sanitation sector in spite of all verbal political commitment to sanitation. "Sanitation", as used here, refers to technologies that are on-site, lower-cost (such as small-bore sewerage) and to associated management, demand, cost and behavioural factors.

\section{Priorities}

The lack of priority typically given to sanitation is reflected in the level of government investment shown in Figure 1.

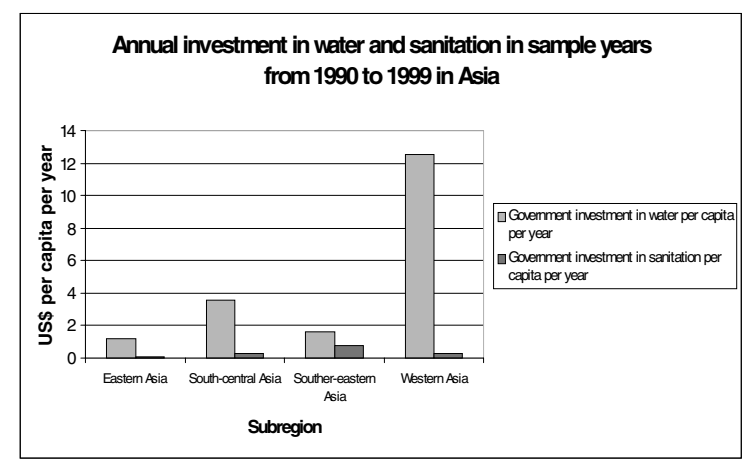

Figure 1. Year 2000 gobal assesment (draft, summer 2000)

\section{Fragmented institutional framework}

Sanitation is interdisciplinary and thus, a range of institutions are usually involved, to the point of fragmenting the overall effort. Those active in one setting or another include:

- Government: Ministries and departments of Public Health, Water Supply, Rural Development, Housing, Local Government, Municipalities, Fisheries...In addition, to these are:autonomous government agencies and local government institutions

- Communityorganizations: Religious groups; community-based organizations such as women's, youth clubs, labour unions...

- NGOs (non-governmental, non-profit sector) and project teams.

- Private sector ranges from individual workers or craftsmen through to large companies.
It is proposed that the optimum institutional arrangement can not be prescribed, it is situational depending on role of government, institutional anchors, coordination, roles of NGOs, control of the private sector, capacity building.

\section{Time frame of sanitation programmes shows near exponential rather than linear growth}

Programming needs to take account of the typical time line of low-cost sanitation programmes. See Figure 2 overleaf.

Expenditure on water facilities tends to be distributed more evenly over time. A different programming time-line for sanitation can imply the need for longer-term commitment. See Figure 3 overleaf.

\section{Demand, mobilization, marketing, education and participation}

There are examples of successful sanitation programmes that concentrated on so-called software leaving construction activities totally in the hands of the private sector. There are more examples of unsuccessful programmes that have only concentrated on construction. Sanitation is, to a large extent, a social phenomenon, rather than a technical one (Wegelin, 2000). Demand, and its cognates-mobilization, marketing, education and participation-are crucial issues. For example: programme management should take into account the initial level of existing demand which may be partially expressed, or not fully informed-and changes in demand.

\section{Example of possible differences in latrines programmes with different entering levels having observed potential of becoming successful}

(See Table 1 overleaf)

Further pilot or research is needed to develop simple measuring tools for different types of demand. There is a need to systematize information on how mobilization and demand-creation approaches can be determined for different situations.

\section{Technology selection and costs}

There are many technologies for low-cost sanitation such as the simple pit latrines, sanplat with pit, Mozambique pit latrine, VIP, double-pit, pour-flush, composting latrine, 


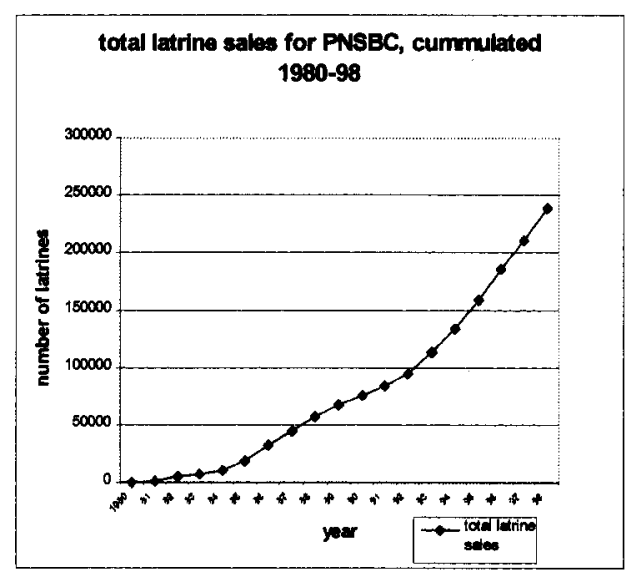

Adapted from Daywell, 1999

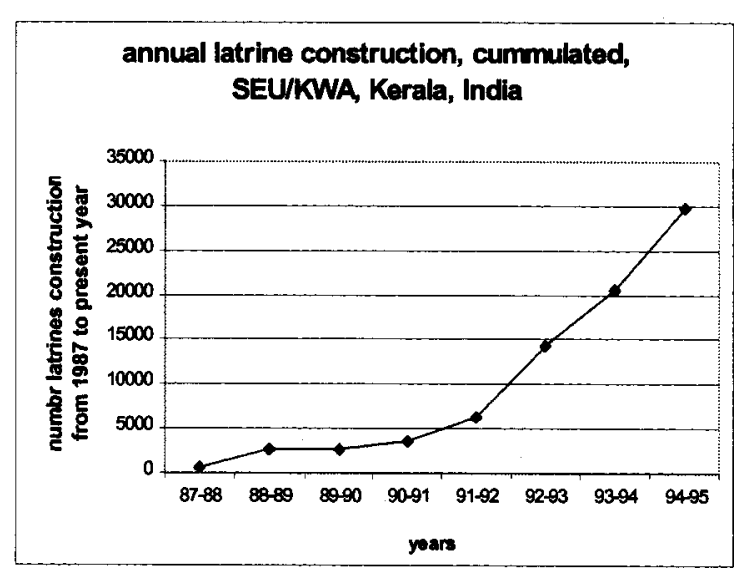

Adapted from Kurup, 1999

Figure 2. Time frame of sanitation programmes shows near exponential rather than linear growth

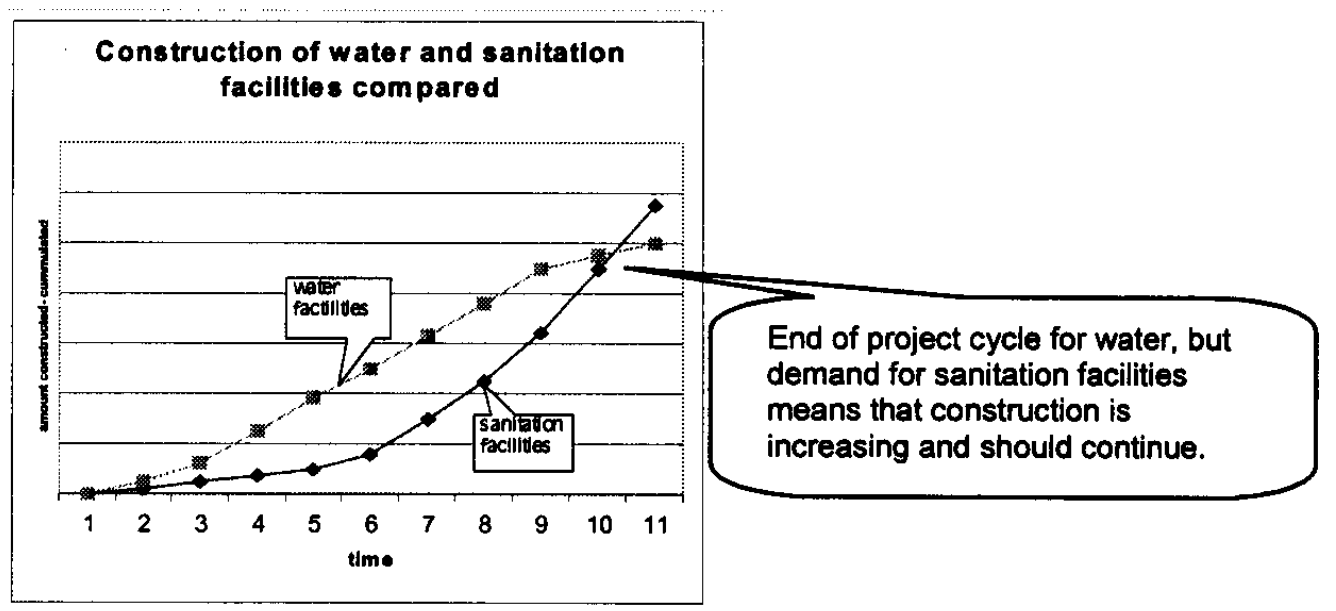

Figure 3. Construction of water and sanitation facilities compared

small bore systems, ecological toilets, mechanical flush, septic tanks). In general, however, current so-called lowcost technologies appear to be too costly for poor households.

It is startling, however, to realize that:

- There is no truly low-cost technology that operates throughout the year in high water table areas. This also affects coastal populations including those in dense urban population located in coastal cities around the world.
- Where population density is high, on-site solutions such as mechanical pit emptying and small bore systems need further refining and promotion.

\section{Costs control}

Cost control relates to the provisoin of adequate product at lowest price. This is particularly important where the public pays all or a percentage of the costs. The following table shows that strong cost control (attempted only by the last group) does indeed result in cost reductions. Greater 
Table 1. Example of possible differences in latrines programmes with different entering levels having observed potential of becoming successful

\begin{tabular}{|c|c|c|}
\hline & $<40 \%$ of the population uses of any kind of latrine & $>40 \%$ use of any kind of latrine \\
\hline & $\begin{array}{l}\text { Demand creation (social marketing, promotion) longer before } \\
\text { construction. }\end{array}$ & $\begin{array}{l}\text { Emphasis on hygiene promotion and behaviours, in addition to } \\
\text { expanding the demand. }\end{array}$ \\
\hline & New projects to be more supply-oriented** & $\begin{array}{l}\text { To be more demand-oriented (for example enlarge technology } \\
\text { choice and enable households to invest in upgrading } \\
\text { technologies. }\end{array}$ \\
\hline & $\begin{array}{l}\text { Capacity building of partners and stakeholders:. NGOs, public } \\
\text { or government-subsidized in rural areas. Possible staff } \\
\text { incentives. }\end{array}$ & $\begin{array}{l}\text { Subsidies are reduced, eliminated or targeted for vulnerable } \\
\text { families. }\end{array}$ \\
\hline & $\begin{array}{l}\text { Identification and dealing with technology issues, for example, } \\
\text { low-cost facilities that operate throughout the year. }\end{array}$ & Need for by-laws and institutionalisation is dealt with. \\
\hline & $\begin{array}{l}\text { Stimulation of private providers in areas of potential high } \\
\text { coverage. }\end{array}$ & Stimulation of private provision in less accessible areas. \\
\hline ** & \multicolumn{2}{|c|}{$\begin{array}{l}\text { "The experience of large-scale programmes such as the PNSBC (Mozambique) suggests that initially a supply-driven approach may be } \\
\text { necessary to establish a platform from which more demand-responsive approaches can be implemented." (Saywell, 1999, p. 46) }\end{array}$} \\
\hline
\end{tabular}

Table 2. Per capita construction costs for latrine facilities

\begin{tabular}{|c|c|c|c|}
\hline Septic tank & 75 & 97 & 100 \\
\hline Sewer & 64 & 100 & $\begin{array}{l}154 \text { (rural) } \\
196 \text { (urban) }\end{array}$ \\
\hline small-bore sewer & 40 & & $\begin{array}{l}140 \text { (rural) } \\
130 \text { (urban) }\end{array}$ \\
\hline Pour-Flush on-site & 30 & 42 & 73 \\
\hline VIP & 29 & 32 & 42 \\
\hline simple pit latrine & 8 & 16 & 56 \\
\hline Other & 6 & 3 & - \\
\hline
\end{tabular}




\begin{tabular}{|l|c|}
\hline Programme of ... & Average unit cost \\
\hline World Bank & Rs. 3500 \\
\hline Various government agencies & Rs. 3000 to Rs. 3500 \\
\hline (NGO) project with local government & Rs. 2000 \\
\hline
\end{tabular}

Kurup, p. 45

Table 5. Subsidies for implementation of water and sanitation per person, Kerala, India 1994

\begin{tabular}{|l|c|c|}
\hline Location & $\begin{array}{c}\text { Piped water supply schemes: avg. per capita } \\
\text { subsidy (Rupees, 1994) }\end{array}$ & $\begin{array}{c}\text { On-site sanitation: avg. per capita subsidy } \\
\text { (Rupees, 1994) }\end{array}$ \\
\hline Nattika scheme & 1,270 & 375 \\
\hline Edapal & 979 & 400 \\
\hline Anjengo & 778 & 375 \\
\hline
\end{tabular}

K. Shordt

effort is needed to ensure cost control with adequate quality.

A heated debate has been ongoing for year about household subsidies for low-cost latrine programmes. However, without having been conclusive. More data is needed to address this issue, including on affordability of technologies, cost control, the impact of subsidies. A comparative example of subsidies for water schemes and on-site sanitation in the same locations shows the following:

The following chart demonstrates how sensitive demand can be to subsidy level. With a year and half after the subsidy was almost eliminated, sales had fallen by $80 \%$. When subsidy levels change, they must do so judiciously, gradually and be supported by careful information activities and monitoring. Subsidies are not sufficiently understood or studied.

\section{Conclusion}

Uniform strategies are not relevant necessarily to different settings. Not enough is known. Past experience has not been studied sufficiently; nor have its lessons been sufficiently applied. We need to experiment, monitor carefully, test approaches, adapt and disseminate them.

\section{Bibliography}

- CAIRNCROSS, SANDY AND R. FEACHEM.

Environmental health engineering in the tropics. John Wiley \& sons., Great Britain. 283 pp.(1983)

- FANG, ANDREW.On-site sanitation: an international review of World Bank experience. UNDP-World Bank Water and Sanitation Programme - South Asia. India. 30 pp.(1999) 


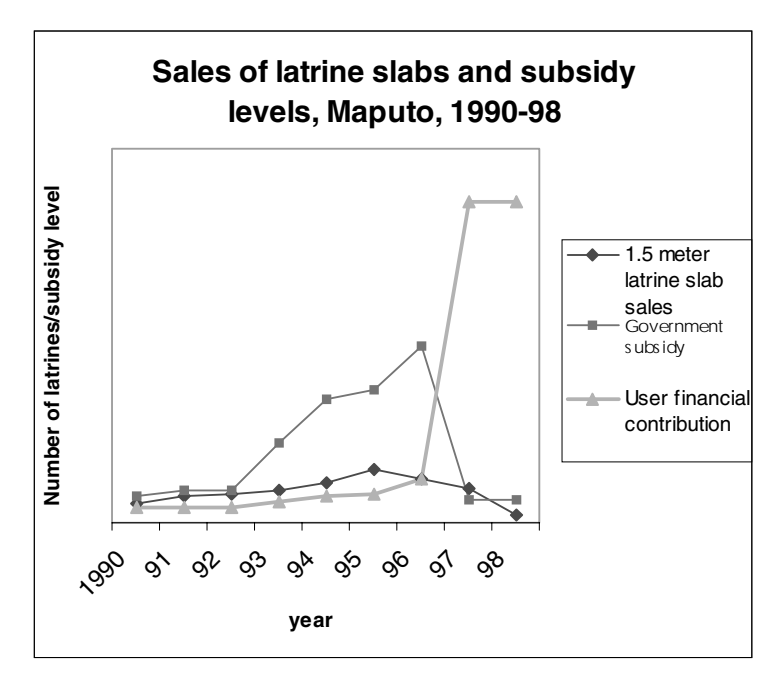

Figure 4. Sales of latrine slabs and subsidy levels

- HOQUE, B.A. et al. Research methodology for developing efficient handwashing options: an example from Bangladesh. Journal of Tropical Medicine and Hygiene. vol. 98, 469-475.(1995)

- HUBLEY, J. Communicating health: an action guide to health education and health promotion. London, UK, MacMillan Press(1993)

- HYDRICK, J.L.Intensive rural hygiene work and pubic bealth education of the public health service of Netherlands India. 60 pp.(1937)
- KURUP, K. B., et al.The community-managed sanitation programme in Kerala: learning from experience. IRC, The Netherlands. (1996)

- MCKEE, N. (1992) Social mobilization and social marketing in developing communities : lessons for communicators. Penang, Malaysia : Southbound, 208 p. (1992)

- MURRE, T., C. VAN WIJK-SIJBESMA AND S. ESREY. Motivating better hygiene behaviour: importance of public heath mechanisms of change. UNICEF, New York. 46 p.(1995)

- SAMANTA, B.B. AND C. A. VAN WIJK .Criteria for successful sanitation programmes in low income areas in the south. UNICEF (Delhi) and IRC (Delft). 10 pp.(1995).

- SAYWELL, DARREN AND CAROLINE HUNT Sanitation Programmes revisited. Task No. 161. London, WELL Study.54 pp.(1999)

- SHORDT, K.Action monitoring for effectiveness. Technical paper series No. 35. IRC, Delft. 2 parts. 260 p.(2000)

- WEGELIN-SCHURINGA,M.(Public awareness andmobilization for sanitation. IRC, The Hague. 18 p.(2000)

- WHO and UNICEF.Year 2000 Global Assessment:Joint Water supply and sanitation monitoring programme. DRAFT. Various pages.( 2000)

EVELINE BOLT. IRC International Water and Sanitation Centre, Delft, The Netherlands.

KATHLEEN SHORDT. IRC International Water and Sanitation Centre, Delft, The Netherlands. 